\title{
Emotional Intelligence on Job Performance of Bank Managers in Sri Lanka
}

\author{
S. Praveena* \\ Department of Business and Management Studies, Eastern University
}

\begin{abstract}
Present day organizations realize that traditional intelligence or Intelligence Quotient (IQ) is not sufficient for developing job performance, work-related behaviour and career advancements of leaders in organizations. The literature suggests that Emotional Intelligence (EI) plays a vital role in the success of managers in the workplace. Hence, the purpose of this study was to investigate the effect of Emotional Intelligence on the job performance of bank managers in Sri Lanka, in order to narrow the research gap.
\end{abstract}

Based on the previous literature showing the relationships among the variables, a conceptual model was developed. The study adopted already validated research instruments. The model was empirically tested by collecting data from bank managers in Sri Lanka. A total of two hundred commercial bank managers were selected for the study using the Convenience Sampling Technique and one hundred and sixty three usable questionnaires were returned. The model was tested with the measurement model and the structural model analysis by using the Partial Least Square technique (PLS). The measurement model analysis was used to establish the item reliability, internal consistency reliability, convergent validity, and discriminant validity and the structural model analysis was used to test the model fit.

The structural model analysis results provided the support for all three hypotheses formulated in this study. Thus, the higher the levels of emotional intelligence of bank mangers the higher the levels of job performance and higher the levels of job satisfaction. This study provides future directions for further research as well.

Keywords: Emotional intelligence, job performance, job satisfaction, measurement model, structural model

\footnotetext{
* Correspondence should be addressed to Ms. S. Praveena, Department of Business and Management Studies, Faulty of Communication and Business Studies, Eastern University of Sri Lanka, Konesapuri, Nilaweli. Sri Lanka. (Email: cochkesti@yahoo.com)
} 


\section{Introduction}

Leaders who have high Emotional Intelligence competencies are more likely than less emotionally intelligent leaders to achieve success in the workplace (Goleman, 1998; San \& O'Higgins, 2012). In today's competitive world, the non-cognitive skill of Emotional Intelligence of managers is the instrument in enhancing their work-related behaviours and their job performance and success, which ultimately leads to organizational success (Goleman, 1998; Derman, 1999; Groves, McEnrue, \& Shen, 2008).

Emotional intelligence provides positive consequences for employees at all levels. Especially it determines the leaders' success in organizations (Groves et al., 2008). Emotional Intelligence is considered twice as important as technical skills and intellectual intelligence for all jobs at all levels (Goleman, 1998). Further Goleman suggested the importance of emotional intelligence for leaders as without it, a person can have the best training in the world, an incisive, analytical mind, and an endless supply of smart ideas, but she/he still won't make a great leader. Further he stated that among star performers with average areas in senior leadership positions, nearly ninety percent of the differences in their profiles were attributable to emotional intelligence factors rather than cognitive abilities.

The banking sector is one of the foremost sectors in any country to boost the economy of any country. Similarly, the banking sector of Sri Lanka is one of the leading sectors in the financial sector and it plays a vital role in the country's development. Compared to the last few decades, new banks are emerging day by day thereby increasing competition among the banks, leading the existing banks to rethink their existing strategies, policies, systems, structures, resources etc. Gaining sustainable competitive advantage through organizational employees could be considered as the best strategy since one of the most important strategic resources in any organization is the human resource. In this regard, organizations must consider the competent employees in achieving success through the people. Many researchers have argued that organizations benefit from having emotionally intelligent employees at the workplace. Emotional Intelligence is proved to be a necessity for successful performance and career development (Kunnanatt, 2008) and for enhancing employee outcomes including job satisfaction, organizational commitment, career commitment, and job involvement (Carmeli,2003; San \& O'Higgins, 2012). 
If managers and employees develop their Emotional Intelligence, they will both benefit. EI enhances employee cooperation, increases motivation, productivity, and profits (Johnson \& Julie, 1999). Further, these scholars pointed out that managers will have a work force willing to engage with passion and employees will have managers who are receptive and open to their needs. How the Emotional Intelligence training programmes influenced quality of service provided by the employees must be taken into consideration. According to the study of Mina and Melika (2011), it was proved that service employees in the banking sector can be trained in EI by means of tailored programmes designed to enhance perceived service quality among bank customers.

Studies on investigating the impact of Emotional Intelligence on Job Performance are lacking, and therefore, the literature is deficient in several aspects. In reviewing the literature, it was found that there were few studies conducted on emotional intelligence in Asia. However, studying the impact of Emotional Intelligence on enhancing performance and employees' outcomes provides a valuable input to the organization in order to identify the right skills and competencies that should be possessed by leaders and managers (Carmeli, 2003; Johnson \& Julie, 1999; Mina \& Melika, 2011).

Sri Lankan commercial banks today have become much more demanding as well as complex and ambiguous places of work. The managers are expected to show their worth in creating conditions in which people can deliver the best results necessitating mastery of a set of new key competencies which includes emotional intelligence and related competencies. However, in the Sri Lankan context, the construct of Emotional Intelligence has only been studied with limited constructs such as organizational learning (Dissanayaka, Janadari \& Chathurani, 2010) and Job Satisfaction (Kappagoda, 2011). However, there is still a need to fill the empirical gap in studying the impact of Emotional Intelligence on Job Performance of managers in the banking industry in Sri Lanka since there were no studies found in testing the relationships between these constructs.

Thus, the research problem of this study is to investigate whether there is a significant relationship between Emotional Intelligence and Job Performance in Sri Lanka. 


\section{Scope of the study}

The current study focused on commercial bank managers in Sri Lanka and four banks are namely, Hatton National Bank, Commercial Bank PLC, People's Bank, and Bank of Ceylon. Two hundred managers were selected using convenience sampling method, representing each province on a proportionate basis.

The objectives of the present study are; to investigate the effect of Emotional Intelligence on Job Performance of managers in the banking sector in Sri Lanka; to investigate the effect of Emotional Intelligence on Job Satisfaction of managers in the banking sector in Sri Lanka; and to investigate the effect of Job Satisfaction on Job Performance of managers in the banking sector in Sri Lanka.

\section{Literature review}

\section{Emotional Intelligence and Job Satisfaction}

Emotional Intelligence is the ability to monitor one's own and others' feelings and emotions, to discriminate among them and to use this information to guide one's thinking and actions, and it is the capacity for recognizing our own feelings and those of others, for motivating ourselves, and for managing emotions well in ourselves and in our relationships (Salovey \& Mayer, 1989; Goleman, 1998). Job Satisfaction refers to the collection of positive feelings and affective responses associated with the job (Spector, 1997; Robbins \& Coulter, 2002; Robbins \& Judge, 2009).

Previous studies proved that there is a positive and significant relationship between Emotional Intelligence and Job Satisfaction (Wong \& Law, 2002; Grandy, 2000). Fisher (2003) found that the emotions in the work place affect Job Satisfaction. Furthermore, he identified constructs of Emotional Intelligence such as interpersonal relations which immediately affect job satisfaction, other than salary and chance of promotion. Carmeli (2003) also found that emotional intelligence has a significant positive effect on job satisfaction by taking a sample of senior managers employed as chief financial officers in the local government authorities in Israel.

Employees who rated their leaders as more emotionally intelligent and effective were satisfied with work (Nowak, 2006). Another study found that leader member exchange mediated the relationship between the follower Emotional Intelligence and both turnover intention and Job Satisfaction (Jordan \& Troth, 2011. 
San and O'Higgins (2012) tested the influences of managers' Emotional Intelligence, leadership styles, and employee outcomes with a sample of three hundred and twenty three managers and their subordinate employees using the Wong Emotional Intelligence Scale. Results showed that managers' transformational leadership style fully mediated the relationship between managers' emotional intelligence and employee job satisfaction. Thus, based on the above justification, the following hypothesis is proposed:

\section{$H_{1}:$ Higher the level of Emotional Intelligence, higher the level of Job Satisfaction of bank managers}

\section{Job Satisfaction and Job Performance}

Job Satisfaction is one of the most prominent variables in the field of organizational behaviour and management since it has been frequently tested in several areas from time to time (Pfeffer, 1994; Fisher, 2003; Robbins \& Judge, 2009). More and more organizations consider Job Satisfaction as a factor in order to retain their employees within the organization (Robbins \& Judge, 2009).

Luthans (1995) found that there is a significant negative relationship between Job Satisfaction and absenteeism. Also Job Satisfaction has been tested with job performance and a positive relationship was found between the two variables (Fisher, 2003). Moreover, research finding proved that satisfied employees effectively perform their tasks and jobs in terms of higher level of performance and productivity (Fisher, 2003). Thus, based on the above justification the following hypothesis is proposed:

\section{$\mathrm{H}_{2}$ : Higher the level of Job Satisfaction, higher the level of Job Performance of bank managers}

\section{Emotional Intelligence and Job Performance}

Dries and Pepermans (2007) conducted a study to reveal Emotional Intelligence and identify the high potential managers. In this study, fifty one high potential and fifty one regular managers were selected as the sample. The results showed that there is a higher level of Emotional Intelligence elements such as assertiveness, independence, optimism, and social responsibility revealed in high potential managers compared to regular 
managers. Also it was found that high potential managers showed a higher level of job performance.

Also it was found that Emotional Intelligence of employees leads to enhance the financial position of the organization. Executives who possessed higher levels of empathy, self-regard, reality testing, and problem solving were more likely to yield high profit-earning companies (Stein et al., 2009). Similarly, another study showed that emotional intelligence of government employees within public organizations has had an impact on Job Performance similar to that in private organizations (Hsi-An \& Susanto, 2010). Thus, based on the above justification the following hypothesis is proposed:

\section{$H_{3}:$ Higher the level of Emotional Intelligence, higher the level of Job Performance of bank managers}

\section{Theoretical Framework}

Emotional Intelligence plays an important role in the success of senior managers in the workplace in order to develop positive work attitudes, behaviour, and outcomes including better performance at the workplace. (Carmeli, 2003). Carmeli empirically examined the extent to which senior managers with a high Emotional Intelligence employed in public sector organizations developed employee outcomes. The results indicated that Emotional Intelligence augments positive work attitudes, altruistic behaviour, and work outcomes in the workplace.

Emotional Intelligence can make the difference between good and poor leaders (Carmeli, 2003). Leaders with high Emotional Intelligence skills are well satisfied with their work (Nowack, 2006). Individuals with high Emotional Intelligence experience continuous positive moods and feelings that generate higher levels of satisfaction and well-being compared to individuals who experience anger, depression and disappointment (Carmeli, 2003; Derman, 1999; Stein et al., 2009). Emotionally intelligent mangers develop emotional attachment to their organizations and even more to their career, and mangers with high Emotional Intelligence often get extremely involved in challenging and complex situations, and they try to get highly involved in their jobs (Carmeli, 2003; Dries \& Pepermans, 2007).

Based on the literature review, it was clear that there are significant relationships among constructs identified for this 
study. Emotional Intelligence has a significant positive effect on Job Performance (Carmeli, 2003; Dries \& Pepermans, 2007; Stein et al., 2009).

In addition to these relationships among the constructs, the job satisfaction was taken as mediator between Emotional Intelligence and Job Performance. Previous studies supported the relationship between these constructs. Emotional Intelligence had a significant positive effect on Job Satisfaction (Carmeli, 2003; Jordan \& Troth, 2011; San and O'Higgins, 2012) and Job satisfaction had a favourable effect on Job Performance (Luthans, 1995; Fisher, 2003).

Therefore, based on the previous studies, the conceptual model for this study was developed. The conceptual model is shown in Figure 1.

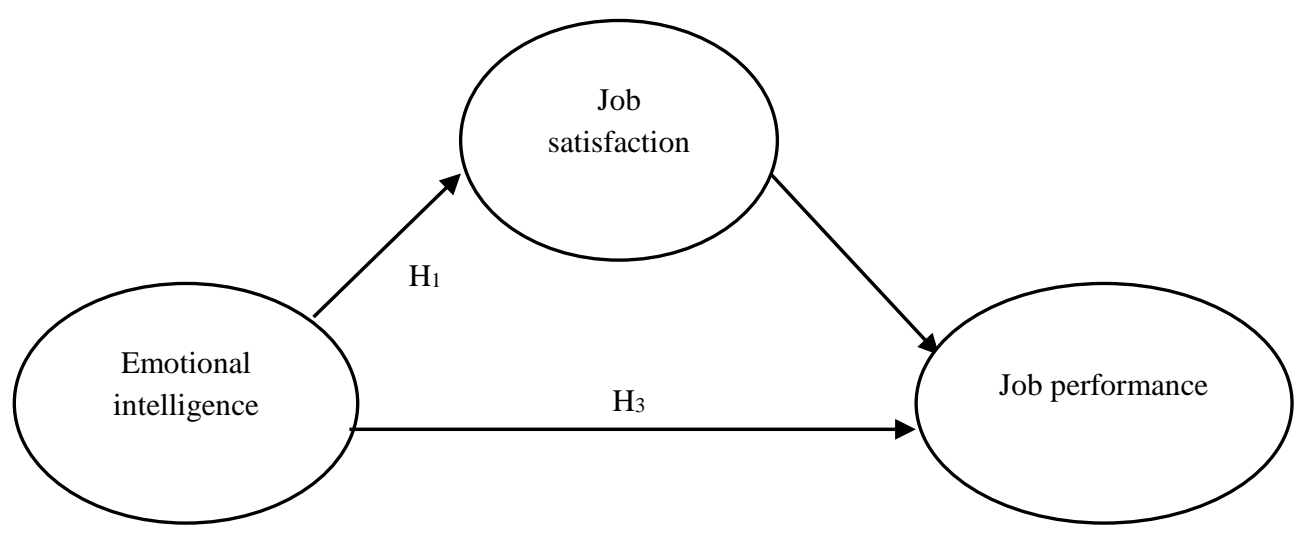

Figure1. Theoretical framework

\section{Methodology}

\section{Overall Approach to Research}

The type of investigation was a correlational study, the extent of researcher interference was minimal, the study setting was non contrived (natural) and the time horizon was cross sectional, and the unit of analysis was individual.

\section{Population and Sample}

The population for this study was commercial bank managers. Four commercial banks were selected for this study; Hatton National Bank, Commercial Bank PLC, People's Bank, and Bank 
of Ceylon. Two hundred managers were selected using convenience sampling method, representing each province on a proportionate basis.

\section{Data Collection}

In this study, an empirical survey was carried out using a selfadministered questionnaire on a seven-point Likert scale $(1=$ strongly agree, $7=$ strongly disagree), whereby respondents were asked to give their agreement or disagreement. The response rate was $81.5 \%$.

\section{Survey Instrument Development}

\section{Emotional Intelligence:}

The current study adopted the self-report of EI of Schutte (1998) including 33 Likert-type scale items in order to measure the emotional intelligence traits of managers. However, factor loadings eliminated 7 items.

\section{Job Satisfaction:}

This study adopted a 6-item measurement developed by Tsui, Egan, and O'Reilly (1992). This study modified items from the question format to statements as a result of consultation regarding these items with selected managers. Factor loadings eliminated one item.

\section{Job Performance:}

The current study adopted a 4-item measurement developed by Perarce \& Porter (1986) and it has been used in the study of Carmeli (2003). Factor leading accepted all items.

\section{Approach to Data Analysis}

Statistical Package for Social Science (SPSS) version 20.0 and SmartPLS version 2.0 (Ringle, Christian Wende, Will \& Alexander, 2005) were the statistical tools used in the current study. 


\section{Findings}

\section{Descriptive Analysis}

Research constructs of emotional intelligence, job satisfaction and job performance were analyzed through mean and its respective standard deviation using the SPSS version 20.0 and they showed higher levels of mean values as shown in Table 1.

Table 1. Descriptive statistics of research constructs

\begin{tabular}{|l|c|c|c|}
\hline \multicolumn{1}{|c|}{ Constructs } & N & Mean & $\begin{array}{c}\text { Standard } \\
\text { Deviation }\end{array}$ \\
\hline Emotional Intelligence & 163 & 5.66 & 0.951 \\
\hline Job Satisfaction & 163 & 5.69 & 1.009 \\
\hline Job performance & 163 & 5.63 & 0.895 \\
\hline
\end{tabular}

\section{Measurement Model Analysis}

The data collected was analyzed using Smart-PLS version 2.0 software. The reliability was tested as a measurement model analysis in this research. Particularly, factor loadings (item reliability) and internal consistency reliability were examined. According to factor loadings, the majority of items were acceptable as the item loadings were above the threshold value of 0.70 (Hair et al., 2011).

However the factor loadings of 07 items of emotional intelligence and 01 item of job satisfaction were below the threshold value of 0.70. The factor loadings for all items were above the threshold value $(0.70)$ when the measurement model analysis was carried out for the third time.

\section{Structural Model Analysis}

The model's explanatory power was assessed by the coefficient of determination, $R^{2}$ and it is 0.824 for the "job performance" construct. This means that the two constructs (emotional intelligence and job satisfaction) explained a substantial proportion $(82.4 \%)$ of the variance in job performance, since $R^{2}>$ 0.75 (Hair et al., 2011).

The strength of the cause-effect relationships was assessed through the path coefficient values $(\beta)$ and bootstrapping was used to test the significance of structural paths using t-Statistics (Hair 
et al., 2011; Wong, 2013). The path coefficients suggested that emotional intelligence has the strongest effect on job performance (0.8816), followed by job satisfaction (0.7513). Thus all the hypothesized path relationships between the constructs were statistically significant. Thus, it is concluded that all the hypothesized path relationships between the constructs: emotional intelligence and job satisfaction $(\beta=0.6894, \mathrm{p}=$ $0.0000)$; job satisfaction and job performance $(\beta=0.7513, \mathrm{p}=$ $0.0000)$; and emotional intelligence and job performance $(\beta=$ $0.8816, \mathrm{p}=0.0010$ ) were statistically significant.

The Figure 2 shows the conceptual model along with its path coefficients and the statistical significant levels where the statistical significant level was set at $95 \%(\mathrm{p}<0.05)$.

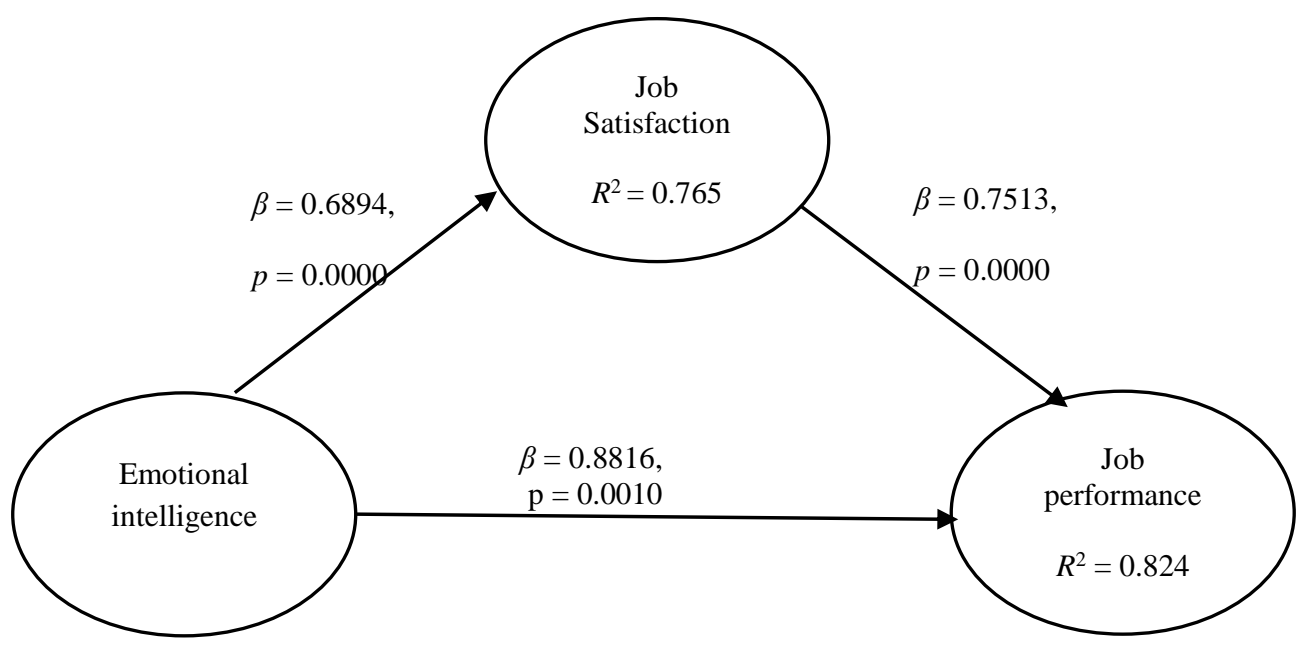

Figure 2. Structural model of the study

\section{Hypotheses Testing}

As shown in Table 2, the hypotheses were tested using the path coefficients $(\beta)$ indicating the strength of the cause-effect relationships between the research constructs. The bootstrapping procedure was used to assess the significance of path coefficient values $(\beta)$. The statistical significance was tested at $95 \%(p<0.05)$ confidence level. 


\begin{tabular}{|l|c|c|c|}
\hline \multicolumn{1}{|c|}{ Hypotheses } & $\begin{array}{c}\text { Path } \\
\text { coefficient } \\
(\beta)\end{array}$ & $\boldsymbol{p}$ value & $\begin{array}{c}\text { Supported/ } \\
\text { Not supported }\end{array}$ \\
\hline $\begin{array}{l}\text { Hypothesis 1: } \\
\text { Emotional intelligence -> Job satisfaction }\end{array}$ & 0.6894 & 0.0000 & Supported \\
\hline $\begin{array}{l}\text { Hypothesis 2: } \\
\text { Job satisfaction -> Job performance }\end{array}$ & 0.7513 & 0.0000 & Supported \\
\hline $\begin{array}{l}\text { Hypothesis 3: } \\
\text { Emotional intelligence -> Job performance }\end{array}$ & 0.8816 & 0.0010 & Supported \\
\hline
\end{tabular}

Table 2: Research hypotheses testing

\section{$H_{1}$ : Higher the level of emotional intelligence, higher the level of job satisfaction of bank managers}

As shown in Table 2, the emotional intelligence affected job satisfaction of bank managers $(p=0.0000)$ with a larger effect size $(\beta=0.6894)$ since emotional intelligence was positively and significantly related to job satisfaction of bank managers $(\beta=$ 0.6894, $p<0.05$ ), supporting $\mathrm{H}_{1}$. This indicated that the bank managers with higher levels of emotional intelligence are likely to display higher job satisfaction in the workplace.

\section{$\mathrm{H}_{2}$ : Higher the level of job satisfaction, higher the level of job performance of bank managers}

As per Table 2, job satisfaction positively affected the job performance of bank managers $(p=0.0000)$ with a larger effect size $(\beta=0.7513)$ since job satisfaction was positively and significantly related to job performance of bank managers $(\beta=$ $0.7513, \mathrm{p}<0.0000$ ), supporting $\mathrm{H}_{2}$. This indicated that the bank managers with higher levels of job satisfaction are likely to display higher job performance in the workplace.

\section{$\mathrm{H}_{3}$ : Higher the level of emotional intelligence, higher the level of job performance of bank managers}

As shown in Table 2, emotional intelligence positively affected the job performance of bank managers $(p=0.0010)$ with a larger effect size $(\beta=0.8816)$ since job satisfaction was positively and significantly related to organizational commitment of bank managers $(\beta=0.8816, p<0.05)$, supporting $\mathrm{H}_{3}$. This indicated 
that the bank managers with a higher level of emotional intelligence are likely to display higher job performance in the workplace.

\section{Discussion}

The major purpose of the study was to examine the extent to which one of the most important managerial skills viz. emotional intelligence leads to job performance of bank managers employed in a financial sector setting.

The first finding of the current study indicates that emotionally intelligent managers are likely to display higher job satisfaction in the workplace. This finding coincided with the earlier findings. Employees with high emotional intelligence experience continuous positive moods and feelings that generate higher levels of satisfaction and well-being compared to individuals who experience feelings and moods such as depression and anger (Carmeli, 2003). Also older managers with a higher level of adaptability were able to perceive higher levels of job satisfaction (Stewart, 2008).

Emotional Intelligence led to job satisfaction among high school English teachers, Anari (2011). Sri Lankan studies also supported that the managers with a higher level of emotional intelligence lead to perceive the job satisfaction of their subordinates. A higher level of emotional intelligence of school principals increased the level of job satisfaction of teachers (Kappagoda, 2011). Hence, it was concluded that higher levels of emotional intelligence of bank managers are likely to display a higher level of job satisfaction in Sri Lanka.

The second finding of the current study shows that the managers with a higher level of job satisfaction are likely to display higher job performance in the workplace. Job satisfaction has been tested with job performance, and a positive relationship was found between the two variables (Fisher, 2003). Moreover, Research findings proved that satisfied employees effectively perform their tasks and jobs in terms of a higher level of performance and productivity (Fisher, 2003). Hence, it was concluded that higher levels of job satisfaction of bank managers are likely to display a higher level of job performance in Sri Lanka.

The last finding of the current study shows that the emotionally intelligent managers are likely to display a higher job performance 
in the workplace. One study showed that emotional intelligence of government employees within public organizations has had an impact on job performance similar to that in private organizations (Hsi-An \& Susanto, 2010). Hence, it was concluded that higher levels of emotional intelligence of bank managers are likely to display a higher level of job performance in Sri Lanka.

\section{Conclusion}

The current study investigated whether there is any significant relationship between emotional intelligence and job performance of bank managers in Sri Lanka. The findings concluded that higher levels of emotional intelligence of bank mangers lead to higher levels of job performance as well as to job satisfaction at the workplace. Further, it was concluded that job satisfaction of bank managers lead to enhance their job performance. Hence, emotional intelligence can be recognized as one of the most critical skills that managers should possess in present day organizations.

\section{Implications of the Study}

The current study narrowed the empirical gap by exploring the role of emotional intelligence on threefold work-related attitude of managers. The findings showed that the managers with a higher level of emotional intelligence in the banking sector can develop higher levels of job satisfaction and job performance at the workplace

\section{Limitations of the Study}

Although this study delivered a new model, implications for theory and practice, there were a few inherent limitations in this study. One limitation is that only job performance and job satisfaction were considered in the study. Apart from these, there are other variables which could also be studied on the grounds of emotional intelligence. Another limitation is the current study explored the role of emotional intelligence only among selected bank managers in Sri Lanka. The reliability of data depended on the respondents' understanding and perceptions as given in the self-reported data, which is also a limitation. 


\section{Future Research Direction}

Even though the current study narrowed the empirical gap as well as provided new findings and insights based on the conceptual model developed in this study, it still provides a pathway for future research. First, the objective of the current study was to explore the role of emotional intelligence among bank managers in Sri Lanka. Therefore, it did not include other managerial level and non-managerial level employees at different organizations in Sri Lanka. Also, future studies may focus on exploring the emotional intelligence among for-profit as well as for not-for-profit organizations. The current study used a relatively new measure of self-report of emotional intelligence items and it showed a higher level of reliability and validity for most of the items. It would be valuable to conduct a future study which compares results of the current study with those that used other acceptable measures of emotional intelligence.

\section{References}

Akintayo D. I. \& Babalola, S. S. (2012). The impact of emotional intelligent on workers' behaviour in industrial organizations. African Journal, 4 (2).

Allen, N. J. \& Meyer, J. P. (1990). The measurement and antecedents of affective, continuance and normative commitment to the organization. Journal of Occupational Psychology, 63, 1-18.

Anari, N. N. (2012). Teachers: emotional intelligence, job satisfaction, and organizational commitment. Journal of Workplace Learning, 24(4), $256-269$.

Buchanan, B. (1974). Building organization commitment: The socialization of managers in work organizations. Administrative Science Quarterly, 22, 533-546.

Carmeli, A. (2003). The relationship between emotional intelligence and work attitudes, behavior, and outcomes: An examination among senior managers. Journal of Managerial Psychology, 18(8), 788-813. 
Chang, L., Shih, C. \& Lin, S. (2010). The mediating role of psychological empowerment on job satisfaction and organizational commitment for school health nurses: A cross-sectional questionnaire survey. International Journal of Nursing Studies, 47(4): 247-276.

Chin, C.H. (2006). A Study of Relationship between Work Values, Job Involvement, and Organizational Commitment among Tiwananees Nurses. Unpublished dissertation, Queensland University of Technology.

Derman, J. (1999). The relationship between the emotional intelligence of family member managers and business success in family business. Dissertation Abstracts International, 55: 2397.

Dissanayaka ,D. R., Janadari, M. P. N. \& Chathurani, R. A. I. (2010). Role of Emotional Intelligence in Organizational Learning: An Empirical Study Based on Banking Sector in Sri Lanka.proceeding of the 2nd International conference on business and information, Kelnaiya, Sri Lanka.

Dries, N., \& Pepermans, R. (2007). Using emotional intelligence to identify high potential: Meta competency perspective. Leadership and Organizational Development Journal, 28(8), 749-770.

Fisher, C. (2003). Why do lay people believe that satisfaction and performance are correlated? Possible sources of a commonsense theory. Journal of Organizational Behavior, 24(3), 753-771.

Gardner, H. (1983). Frames of mind: The theory of multiple intelligences. New York: Basic Books.

Goleman, D. (1995). Emotional Intelligence: Why It Can Matter More than IQ. New York: Bantam Books.

Goleman, D. (1998). Working with Emotional Intelligence. New York: Bantam Books.

Groves, K. S., McEnrue, M. P \& Shen, W. (2008). Developing and measuring the emotional intelligence of leaders. Journal of Management Development, 27(2), 225-250. 
Guleryuz, K., Guney, S., Aydin, E.M., \& Asan, O. (2008). The mediating effect of job satisfaction between emotional intelligence and organizational commitment of nurses: a questionnaire survey. International Journal of Nursing Studies, 45(11), 1625-1635.

Hair, J. F., Ringle, C.M \& Sarstedt.M. (2011). PLS-SEM: Indeed a Silver Bullet. Journal of Marketing Theory and Practice 19(2): 139-151

Hsi-An,S. \& Susanto,E. (2010). Conflict management styles, emotional intelligence, and job performance in public organizations. International Journal of Conflict Management, 21(2), $147-168$.

Johnson, P. R. \& Julie, I, (1999). Organizational benefits of having emotionally intelligent managers and employees. Journal of Workplace Learning, 11(3), 84-88.

Jordan, P. J. \& Troth, A. C. (2011). Emotional intelligence and leader member exchange: The relationship with employee turnover intentions and job satisfaction. Leadership Organizational Development Journal 32(3), 260-280.

Jordan, P. J. \& Troth, A. C. (2011). Emotional intelligence and leader member exchange: The relationship with employee turnover intentions and job satisfaction. Leadership Organizational Development Journal 32(3), 260-280.

Kanungo, R. N. (1982). Measurement of job and work involvement. Journal of Applied Psychology. 67(3), 341-349.

Kappagoda, S. (2011). Managers' Emotional Intelligence and its impact on Non - Managerial Employees' Job Satisfaction in the Banking Sector in Sri Lanka. Proceedings of international conference on MTIM, University of Rajarata.

Kappagoda, S. (2013). Emotional intelligence of the managers in the banking sector in Sri Lanka. Proceeding of International journal of research in commerce, IT \& Management, 3(6).

Kunnanatt, J. T. (2008). Emotional intelligence: theory and description: A competency model for interpersonal effectiveness. Career Development International, 13(7), 614629. 
Lodahl T. M. \& Kejner M. (1965). The definition and measurement of job involvement. Journal of Applied Psychology, 49, 2433.

Luthans, F. (1995). Organizational behavior. 7th ed. McGraw-Hill. Mayer, J. D. \& Salovey, P. (1997). What is emotional intelligence? In: Salovey, P. \& Sluyter, D.J. (Eds.) Emotional Development and Emotional Intelligence. New York: Basic Books.

Mayer, J. D., Roberts,R. D. \& Barsade, S. G. (2008). Human Abilities: Emotional Intelligence. Annual Review of Psychology, 59: 507-536.

Meyer, J. \& Allen, N. (1991). A three-component conceptualization of organizational commitment. Human Resource Management Review, 1, 61-89.

Meyer, J. \& Allen, N. (1997). Commitment in the workplace. Thousand Oaks, CA: SAGE Publications.

Mina, B. \& Melika, S. (2011). Effects of an emotional intelligence training program on service quality of bank branches. Managing Service Quality, 21(5), 552 -567.

Mowday, R.T., Porter, L.W. \& Stress, R.M. (1982). Employee organization linkages: The psychology of commitment, absenteeism and turnover. San Diego: Academic Press.

Najafpour, E. (2008). An investigation of the relationship between emotional intelligence and job involvement in a Penang manufacturing company. Unpublished dissertation Universiti Sains Malaysia.

Nowack, K. (2006). Emotional Intelligence and Employee Engagement: Creating a Psychologically Healthy Workplace. Leadership.

O'Reilly, C. A. \& Chatman, J. (1986). Organizational commitment and psychological attachment: the effects of compliance, identification and internalization on pro-social behaviour. Journal of Applied Psychology, 71(3): 492-499.

Paullay, I., Alliger, G. \& Stone-Romero, E. (1994). Construct validation of two instruments designed to measure job 
involvement and work centrality. Journal of Applied Psychology, 79, 224-248.

Pfeffer, J. (1994). Competitive advantage through people: Unleashing the power of the work force. Boston: Harvard Business School Press.

Porter, L. W., Steers, R. M., Mowday, R. T. \& Boulian, P. V. (1974). Organizational Commitment, Job Satisfaction, and Turnover among Psychiatric Technicians. Journal of Applied Psychology, 59, 603-609.

Ringle., Christian,M., Wende, Will, S. \& Alexander. (2005). SmartPLS Release 2.0 (beta). Retrieved November 02, 2014, 2011, http://www.smartpls.de.

Robbins, S. P. \& Coulter, M. (2002). Management, 7th ed. Upper saddle River: Prince Hall International.

Robbins, S. P. \& Judge, T. A. (2009). Organizational Behavior, 13th Ed. Prentice-Hall Inc.

Salovey, P. \& Mayer, J. D. (1990). Emotional intelligence. Imagination, Cognition and Personality, 9(3), 185-211.

San, L. C. \& O'Higgins, E. R. E. (2012). Enhancing employee outcomes: The interrelated influences of managers' emotional intelligence and leadership style. Leadership \& Organization Development Journal, 33(2) 149 - 174.

Sarboland, K. (2012). Assessment of the Relationship between Emotional Intelligence and Organizational Commitment of Employees: A Case Study of Tax Affairs Offices. Iran Journal of Basic Applied Sciences, 2(5), 5164-5168.

Schutte, N. S., Malouff, J. M., Hall, L. E., Haggerty, D. J., Cooper, J. T., Golden, C. J. \& Durkheim, L. (1998). Development and validation of a measure of emotional intelligence. Personality and Individual Differences, 25, 167-177.

Spector, P. (1997). Job Satisfaction: Application, Assessment, Causes and Consequences. London: Sage Publications.

Stein, S. J., Jeremy, A. P. P. \& Gill Sitarenios, Y. (2009). Emotional intelligence of leaders: a profile of top executives. 
Leadership \& Organization Development Journal, 30(1), 87101.

Stewart, G. L. (2008). The relationship of emotional intelligence to job satisfaction and organization satisfaction. (Unpublished Dissertation), Regent University.

Tsui, A.S., Egan, T.D. and O'Reilly III, C. A. (1992). Being different: Relational demography and organizational attachment. Administrative Science Quarterly, 37, 549-579.

Uygur, A. \& Kilic, G. (2009). A study into organizational commitment and job involvement: An application towards the personnel in the central organization for Ministry of Health in Turky. Ozean Journal of Applied Sciences, 2(1), 113-125.

Yang, F. H. \& Chang, C. C. (2008). Emotional labour, job satisfaction and organizational commitment amongst clinical nurses: A questionnaire survey. International Journal of Nursing Studies, 45(6), 879-887.

Received: 9-4-2015 Revised: 6-8-2015 Accepted: 16-8-2015 
